\title{
A ANTROPOLOGIA EM FACE DA PSICANÁLISE
}

\author{
Egon Schaden \\ Professor da Universidade de São Paulo
}

A Antropologia Cultural dos últimos três decênios é marcada de maneira inconfundível pela influência que nela exerceu e continua exercendo o desenvolvimento das teorias psicanalíticas. Para serem bem compreendidas as razões da inquietude que se apoderou dos antropólogos com o advento das idéias de Freud e seus discípulos, cumpre situar o aparecimento da psicanálise não sòmente no contexto das cogitações antropológicas dos anos que precederam à Primeira Guerra Mundial, como, ainda, pôr em relêvo as suas linhas dominantes em confronto com o próprio objeto da Antropologia. Tomando-se êste em seu sentido mais amplo e compreensivo, e por isso mesmo mais pretensioso, o de encontrar, em plano científico, uma resposta satisfatória para o que Thomas Henry Huxley chamava "a questão de tôdas as questões", a saber, o lugar do homem na natureza, desde logo se percebe o fato, à primeira vista paradoxal, de que Sigmund Freud, em que pese à originalidade e ao caráter revolucionário de suas idéias, se apresenta no cenário do pensamento não como figura isolada, mas colaborando num sentido bem definido no movimento antropológico dêstes últimos cento e poucos anos. E' êste um período em que a Antropologia, no afã de elaborar uma imagem científica da natureza humana, teve de constituir as suas bases teóricas e os seus métodos de investigação em oposição à imagem do homem que the fôra legada pelos pensadores setecentistas do idealismo filosófico e do iluminismo - imagem envolta num halo de misticismo pré-científico, que não satisfazia em absoluto à mentalidade naturalista inaugurada no século dezenove.

Foi grande o número dos pensadores que, ora acertando, ora errando, contribuiriam para o desmantelamento dessa imagem do homem, que não era nem religiosa nem científica, a fim de substituí-1a por uma concepção diversa, apoiada em princípios de investigação metódica da realidade objetiva. Dessa coorte se destacam, porém, três espíritos vigorosos, que, lançando teorias heterodoxas e uma curiosa combinação de idéias certas com visões erradas, desencadearam não sòmente as mais vivas discussões no plano das lides intelectuais, mas vieram constituir em grande parte a imagem do mundo peculiar ao homem civilizado do século vinte. Trata-se de Marx, Darwin e Freud. Não é preciso ser marxista, nem 
darwinista, nem freudista para admitir essa verdade. Muito ao contrário, na ortodoxia dêsses pensadores heterodoxos é que as suas doutrinas, encerrando-se na rigidez de sistemas fechados, perdem em grande parte a sua capacidade de motivação, salvo, é claro, como ideologias ou instrumentos de dominação política. No plano do pensamento científico, a sua fôrça reside no impulso que podem provocar, no nervosismo que podem causar, na focalização de problemas cruciais anteriormente desdenhados ou nem sequer percebidos.

Só quem não aprendeu a pensar com independência é que consegue enclausurar-se numa teoria hermética. Enquanto doutrina, o sistema de Freud, da mesma forma como os de Marx e Darwin, não cabe nos quadros da Antropologia científica. Poucos antropólogos são freudistas, muitos ou quase todos são de algum modo - talvez sem o saberem - discípulos de Freud, na medida em que a psicanálise thes proporciona elementos para uma compreensão menos superficial e menos restrita do homem.

Mühlmann apontou o fato de que as Psicologias analíticas - de Freud, Adler e Jung -, acentuando a necessidade de investigar as camadas profundas da alma, se beneficiaram, de um lado, de um clima espiritual criado pelo romantismo, o descobridor da importância decisiva do inconsciente na vida humana, ao passo que do outro se enquadram em tôda uma série de sistemas psicológicos de desmascaramento da natureza humana: entre outras, são a "Psicologia desencantadora" de Max Weber, a Sociologia do saber, de Max Scheler e Karl Mannheim, a Psicologia social da fama e do mito-do-gênio, de Lange-Eichbaum ${ }^{1}$. Não há dúvida, porém, de que nenhuma teoria psicológica influenciou de tal maneira a Antropologia como a psicanálise.

As relações entre a Antropologia e a Psicologia vinham de longe. Tempos houve em que a primeira teve a pretensão de fornecer novas bases à segunda. Foi o que se deu com a teoria das idéias elementares e idéias étnicas, lançada por Bastian, e sôbre a qual não sòmente se esperava construir tôda a metodologia etnológica, como ainda, e a título de corcamento final, tôda uma nova Psicologia - uma Psicologia étnica em substituição à individual, que, no dizer de Bastian, declarara falência. Por outro lado, a Antropologia, na medida em que evita perder de vista a complexidade da natureza humana (que the cumpre perscrutar), sempre sentiu a necessidade de receber e acolher recursos teóricos e metodológicos de fora, viessem de onde viessem, contanto que aplicáveis ao seu objeto de investigação. E' decorrência natural de seu caráter de ciência integrativa, que lhe dá especial sensibilidade diante de tôdas as inovações que se apresentem em campos afins. Quanto à psicanálise, formulava ela um novo conceito da natureza humana. Havia na Antropologia uma vaga concepção da "unidade psíquica" do homem, mas, como bem diz Hallowell, sem "referência a quaisquer sistemas que pudessem ser relacionados 
diretamente com a dinâmica da estrutura da personalidade humana". Em que consiste, a êste respeito, a contribuição da teoria psicanalítica? Em apontar e analisar o que se the afigura o denominador comum do comportamento de todo ser humano, qualquer que seja a cultura em que êste tenha formado a sua personalidade, a saber, o papel do inconsciente e das raízes biológicas da conduta, bem como a ubiqüidade de conflito, repressão, sublimação, racionalização e outros mecanismos de ajustamento psíquico. Desde logo, os antropólogos, procurando aproveitar os ensinamentos de Freud e sua escola, aceitam-nos, não como teoria psicanalítica, mas enquanto contribuição psicológica pura e simples. E' o que se dá com Sapir, quando encara com acentuado ceticismo "o complexo de Édipo como imagem normativa ou interpretação definida de certos símbolos ou a natureza marcadamente sexual de certas reações infantis", sem com isso deixar de antever a extraordinária repercussão que as idéias de Freud haveriam de ter no campo dos estudos antropológicos².

A pretensão de Freud não se limitava, entretanto, à de indicar à Antropologia possíveis pistas para o levantamento de problemas. Insistia êle em ter descoberto, com a teoria da libido, uma chave universal para a interpretação das culturas, as quais, em última análise, seriam, pois, redutíveis às características biológicas do homem. "Padrões culturais são conseqüências de impulsos libidinais" é, para o freudista ortodoxo, a fórmula orientadora para tôda e qualquer compreensão antropológica ${ }^{3}$.

A repressão de impulsos libidinais e sua repercussão no psiquismo individual remontam inclusive os sistemas de valores encontrados nas diferentes épocas da humanidade e em quaisquer regiões da terra. Sôbre a base da tipologia das enfermidades psíquicas, o fenômeno da consciência moral se reduz a uma forma de manifestação do complexo do pai, e a religião a uma simples ilusão, cujas raízes mergulham, por sua vez, nas profundezas do inconsciente. A uma obra sôbre a religião, publicada em 1927, Freud deu mesmo o título "Die Zukunft einer Illusion", nela estigmatizando as religiões como construções fantásticas, incompatíveis com o conhecimento científico da realidade e a tal ponto absurdas que deveriam $\mathrm{s} \in \mathrm{r}$ comparadas com alucinações. Tais idéias, recebidas naturalmente com aplausos por ateus e agnósticos e com não menor indignação pelas adeptos dos vários credos religiosos, visavam a fundamentar uma concepção do homem sôbre base exclusivamente naturalista, em que não houvesse resquício de antigas imagens idealizadoras. Dado o relativo hermetismo das interpretações, havia mesmo a tendência manifesta de o freudismo assumir o caráter de base doutrinária de uma nova concepção do mundo, ainda mais por se ver obrigado a desenvolver uma terminologia própria, que ao não-iniciado se afigura necessàriamente como portadora de cunho esotérico. 
Além de formular explicações gerais da cultura ou de determinadas esferas culturais, como a religião, Freud se apresenta no campo da Antropologia com contribuições tendentes a resolver problemas específicos dessa ciência. Foi assim que se aventurou a formular no "Totem und Tabu" (1912) uma interpretação psicanalítica do totemismo e da proibição do incesto. E' a conhecida história da hipotética comunidade primitiva, constituída de um homem adulto e várias mulheres e crianças. Expulsos da horda pelo pai ciumento à medida que alcançam idade adulta, os filhos varões afinal o assassinam e comem, passando a viver com as irmãs. Arrependidos, porém, domina-os um complexo de culpa, e êste seria a origem da instituição do totemismo, com a proibição de consumir o animal totêmico e de casar com pessoa do mesmo clã.

Os antropólogos, por assim dizer unânimemente, receberam a teoria exposta em "Totem und Tabu" com attiude tão negativa que na época dificilmente se poderia ter imaginado a influência que os conceitos de Freud viriam desempenhar mais tarde no estudo das culturas humanas. Tôda a interpretação foi remetida para o reino das construções fantásticas. Kroeker, Malinowski e outros submeteram o livro a cerrada crítica, mostrando a inconsistência da argumentação. Por seu lado, Freud se aferrou à tese até o fim da vida. Ainda em 1939 publicou “Der Mann Moses und die monotheistische Religion", em que insiste em considerar válida a estrutura anteriormente apresentada. No sentido das críticas de Kroeber faz apenas uma concessão: "o assassínio do pai não foi um acontecimento ínico, mas na realidade se estendeu por um período de milênios" ${ }^{4}$.

E, ainda em 1947, Géza Róheim, que chegou a realizar investigações de campo sôbre totemismo entre aborígenes australianos, quebra lanças a favor de "Totem e Tabu", assinalando-lhe o mérito de "ter criado a antropologia psicanalítica, de nela se ter estabelecido definitivamente a posição central do complexo de Édipo para a compreensão da sociedade humana, sem mencionar itens "menores", como os papéis da ambivalência, a magia, projeção e origem dos espíritos" 5 .

Se é preciso não esquecer que a apologia da contribuição de Freud no sentido de solucionar problemas específicos da Etnologia parte de psicanalistas e não de antropólogos, não é menos certo, como assinala Hallowell, que os antropólogos não tardaram em descobrir que a teoria de Freud levava a conseqüências que o próprio Freud não vira. Sobretudo o alcance da hipótese de que o tratamento e as experiências da primeira infância influem de forma decisiva no desenvolvimento do tipo de personalidade; de que os pais ou outros responsáveis pela educação da criança são substitutos do todo cultural mais amplo, e de que a socialização como transmissão de cultura de uma geração para outra é, em outro plano, o processo de estruturação da personalidade individual. 
Possivelmente as "diferenças grupais no tratamento infantil estivessem em correlação com uma estrutura típica de personalidade, de um lado, e um padrão cultural característico, do outro. E uma vez que a teoria psicanalítica acentuava a importância crucial de certas espécies de experiência infantil, como o treinamento de toilette e o desmame, era possível obter informação sôbre êsses fatos através de investigação de campo" ".

Antes da psicanálise, não havia trabalhos sistemáticos sôbre a situação social e fenômenos psíquicos dos imaturos em sociedades primitivas. Com $c$ advento dessa teoria e o concomitante estabelecimento de uma compreensão mais satisfatória da relatividade cultural sôbre a base do configuracionismo, começam os antropólogos, sobretudo nos Estados Unidos, a observar os processos de educação infantil em diferentes sociedades tribais. Essa inovação vinha de encontro a uma necessidade sempre sentida pela Antropologia norte-americana: a de firmar o seu status pela colaboração em alguma tarefa de ordem prática. Compreende-se, pois, que, uma vez encontrada, para a psicanálise, a ponte de ligação entre o psíquico-individual e o sócio-cultural - ou seja, de um lado, as experiências infantis padronizadas e, do outro, um tipo correspondente de personalidade - não tardasse a surgir, como lembra Erasmus ${ }^{7}$, a transposição de uma Psicologia terapêtica para o plano da terapêtica social. Era a primeira vez que se oferecia ao antropólogo oportunidade para abandonar a tôrre de marfim e apresentar-se com intuitos de aplicação. São propósitos manifestos, por exemplo, nas contribuições de Margaret Mead, notável propugnadora da Antropologia aplicada nos Estacios Unidos. Tal é a orientação prática aí desenvolvida que Linton chega a proclamar em 1940 que a Psicologia e a Antropologia têm por finalidade comum "o contrôle e a direção consciente da existência humana" 8.

Para que os antropólogos fôssem capazes de beber o vinho freudiano, queixá-se Róheim, foi preciso que Kardiner - considerado neofreudista - o diluísse, apresentando apenas determinadas perspectivas psicanalíticas, como as concernentes às relações entre pais e filhos, entre sociedade e indivíduo, à importância da vida sexual e outras mais. Mas não padece dúvida que a aproximação realizada por Kardiner entre a Antropolog̣ia e a psicanálise foi devida, em primeiro lugar, e não em segundo, ao desenvolvimento da noção operacional da personalidade básica. E' que êle não sòmente despiu os conceitos psicanalíticos de grande parte do vocabulário esotérico de que de ordinário vêm revestidos, como ainda, e em especial, tratou de elaborar um recurso metodológico que, evitandc a explicação de símbolos por meio de símbolos, pudesse ser compreendido e utilizado pelo antropólogo, por não divergir, em es- 
sência, da maneira por êste tradicionalmente seguida na discussão e análise de seus problemas.

Compreende-se que aos psicanalistas ortodoxos, entre êles o próprio Róheim, tal diluição do vinho freudiano não possa satisfazer de maneira alguma, a ponto de lhe negarem mesmo ter conservado o espírito da teoria. Tal recriminação talvez tenha a sua razão de ser, como, aliás, se poderia deduzir da posição teórica assumida por Linton após vários anos de estreita - e, como êle reconhece, fecunda - colaboração com o psicanalista Kardiner. Encarada, porém, do ponto de vista da Antropologia, a contribuição não deixa de ser realmente positiva e frutífera, menos pela apresentação do conceito de personalidade básica - em que não havia talvez novidade tão essencial para o antropólogo - do que por focalizar de maneira sistemática as relações causais entre as técnicas de tratamento infantil, de um lado, e os padrões dominantes na cultura, na sociedade e na estrutura da personalidade, do outro. Coisa em que, aliás, Kardiner fôra precedido - se menos sistemática, nem por isso menos decididamente - por antropólogos que haviam procurado aproveitar a lição da psicanálise, como Margaret Mead, Gregory Bateson e cittros.

Quantc à posição de Linton, há pouco referida, reconhece êle na psicanálise o mérito capital - sobretudo em comparação com as técnicas de aplicação de testes - de serem nela consideradas as personalidades como contínuos dinâmicos e de, através do estudo e da comparação de histórias de vida, não se contentar com a descoberta de conteúdos de personalidade, mas de, ao contrário, focalizar os processos de desenvolvimento, rrescimento e mudança. Por outro lado, não deixa de se referir ao estado pouco satisfatório em que se encontra a psicanálise no tocante ao desenvolvimento de técnicas objetivas utilizáveis pelo antropólogo. E acrescenta: "Apesar da aparente validade de muitas das conclusões psicanalíticas, a maioria dessas conclusões foi alcançada sôbre a base de juízos subjetivos, não sendo suscetíveis da espécie de prova requerida por trabalhadores no domínio das ciências exatas" 9 .

Ao que se vê: uma atitude sensata, que não exclui, mas, ao contrário, reclama a colaboração entre as diferentes ciências que perscrutam a natureza humana, sem dispensar, entretanto, a necessária comprovação dos resultados obtidos.

Mais radical é a posição dos chamados anti-reducionistas, como Kroeber nos Estados Unidos e Evans-Pritchard na Inglaterra, que desejam ver resguardada à outrance a especificidade do fenômeno cultural, recusando-se a reduzi-lo a simples decorrência de necessidades quer biológicas, quer psíquicas. Evans-Pritchard estabelece, por isso, nítida barreira entre o psíquico e o social e, por conseguinte, entre as disciplinas que os estudam, de vez que, como explica, obtêm os seus resultados em 
níveis de abstração diferentes. E é peremptório ao estabelecer que "as duas disciplinas só podem ser de valor - e podem ser de grande valor - uma para a outra, se cada uma prossegue independentemente em suas pesquisas de seus próprios problemas com seus próprios métodos" 10 .

Como quer que seja: De um lado temos a primeira reação crítica dos antropólogos diante da psicanálise, como por exemplo, a de Malinowski e Kroeber, ambos desiludidos após reais tentativas de pôr as idéias de Freud a serviço da solução de problemas antropológicos. Do outro temos, em primeiro lugar, no plano das pesquisas, dezenas de trabalhos de campo realizados, sob inspiração freudiana, sôbre a formação ou características da personalidade nas mais diversas populações tribais como, por exemplo, os Apache, Ojibwa, Saulteaux, Balineses, Kaingáng, Mohave, Maori, Pilagá, Navaho, Aloreses e muitas outras; no plano da teoria, contribuições - não freudianas, mas inspiradas por Freud como a de Ruth Benedict sôbre anormalidade relativa e anormalidade absoluta, de Du Bois, Opler, Róheim, Kardiner, Bastide, tôdas elas tendentes a libertar a Antropologia do perigo de se perder num culturalismo estéril e a mostrar que cultura e personalidade não são senão facetas de uma só realidade complexa. Mesmo quando chegam a conclusões contrárias às da psicanálise, esta tem a seu crédito o impulso frutificador, o ter despertado e avivado na Antropologia contemporânea a consciência do problema das relações entre a psique individual e as instituições da sociedade. Se na origem da Antropologia encontramos êsse problema formulado de maneira vaga sôbre a base de reações humanas elementares, no sentido de Bastian, se depois, pela reação à interpretação evolucionista das culturas, o interêsse se deslocou para um historicismo extremo, a psicanálise veio contribuir com novas perspectivas para que a solução pudesse ser tentada, com maior probabilidade de êxito, quer no plano tipológico, quer no funcional.

Resumindo: Se foram pobres as contribuições diretas da teoria de Freud para o conhecimento antropológico, não deixam de ser úteis as perspectivas que proporcionou aos pesquisadores. A Antropologia deve, ela mesma, reelaborar os elementos que the são proporcionados para a realização satisfatória da tarefa que the é peculiar, e de que ninguém mais se pode encarregar, a de construir uma imagem científica integrada da natureza humana.

\section{NOTAS}

(1) Wilhelm E. Mühlmann, Geschichte der Anthropologie, Universitäts-Verlag, Bonn, 1948; págs. 178-180.

(2) Cf. A. Irving Hallowell, "Psychology and Anthropology", contribuição ao volume For a Science of Social Man, organizado por John Gillin, Nova York, 1954; pág. 207. 
(3) Silvano Arieti, "Some Basic Problems Common to Anthropology and Modern Psychiatry". American Anthropologist, 58, pág. 34; 1956.

(4) A. L. Kroeber, The Nature of Culture, The University of Chicago Press, 1952; pág. 309.

(5) In. Douglas G. Haring, Personal Character and Cultural Milien, Syracuse University Press, 2a. ed., 1949; pág. 568.

(6) Op. cit., pág. 206.

(7) Charles Erasmus, Las Dimensiones de la Cultura, Bogotá, 1953; págs. 100-101.

(8) Apud Erasmus, ibid.

(9) Ralph Linton, The Cultural Background of Personality, Appleton, Nova York e Londres, 1945 ; pág. 4.

(10) E. E. Evans-Pritchard, Social Anthropology, Cohen and West, Londres, 1951; pág. 46. 